\title{
MATERI NASIONLISME PADA BUKU TEKS IPS SD BERDASARKAN KURIKULUM KTSP
}

\author{
Abd. Malik Dachlan ${ }^{1}$, Muhari $^{2}$, Waspodo Tjipto Subroto ${ }^{3}$ \\ ${ }^{1}$ Mahasiswa Program Pascasarjana, Prodi Pendidikan Dasar, Universitas Negeri Surabaya, \\ ${ }^{2 \& 3}$ Dosen Pascasarjana, Prodi Pendidikan Dasar, Universitas Negeri Surabaya \\ e-mail: alex.anakdesa@gmail.com
}

Received : Maret 2019

Reviewed : April 2019

Accepted : Mei 2019

Published : Mei 2019
ABSTRACT

This research aims to determine how nationalism is narrated in Social Science Education textbooks elementary fourth grade based on SBC curriculum 2006. This research is a descriptive qualitatively used content analysis of textbooks fourth grade social studies and works Tantya Hisnu P. Winardi with the titles of Social Sciences for Primary School and works Retno Heny Pujiati and Umi Yuliati with the title of the book Smart Social Sciences Grade 4 Primary School. The method of this research is analysis of the content (content analysis). Techniques of the content analysis covers the following efforts: classification symbols used in the communication, the criteria in the classification, the prediction and the use of certain techniques to make predictions. Overall the materials presents nationalism has contextual and proportionate without ignoring standards of competence and basic competence curriculum SBC as what is described in the material by text books I and II. Both textbooks itself reflect the real corresponding to everyday life. Description of the material also presents academic, persuade students to think, practice, direct labor, and social skills. The material also involves daily activities, daily life, social issues, and everyday learners.

Keywords: Text Book, Social Science Education, School Based Curriculum (SBC), Nasionalisme.

\section{ABSTRAK}

Penelitian ini bertujuan untuk mengetahui bagaimanakah nasionalisme dinarasikan dalam buku ajar IPS SD kelas IV SD berdasarkan kurikulum KTSP 2006. Penelitian ini merupakan deskriptif kualitatif dengan menggunakan metode analisis isi terhadap buku ajar IPS kelas IV karya Tantya Hisnu dan P. Winardi dengan judul buku Ilmu Pengetahuan Sosial untuk SD/MI dan karya Retno Heny Pujiati dan Umi Yuliati dengan judul buku Cerdas Pengetahuan Sosial untuk Kelas 4 SD/MI. Metode yang digunakan dalam penelitian ini adalah analisis isi (content analysis). Secara teknik content analysis mencangkup upaya-upaya : klasifikasi lambang-lambang yang di pakai dalam komunikasi, menggunakan kriteria dalam klasifikasi, dan menggunakan prediksi dan menggunakan teknik tertentu dalam membuat prediksi. Secara keseluruhan materi nasionalisme yang disajikan telah kontekstual dan proporsional tanpa mengabaikan standar kompetensi dan kompetensi dasar kurikulum KTSP, apa yang di uraikan dalam materi oleh buku ajar I dan buku ajar II adalah persoaalan nyata yang sesuai dengan kehidupan sehari-hari. Uraian materi yang disajikan juga sudah memuat kecakapan akademik, mengajak siswa berpikir, praktek, kerja langsung, serta kecakapan sosial, materi yang disajikan juga telah melibatkan kegiatan sehari-hari, kehidupan sehari-hari, melibatkan masalah-masalah sosial sehari-hari yang ada dilingkungan peserta didik.

Kata Kunci: Buku Teks, IPS, Kurikulum Tingkat Satuan Pendidikan (KTSP), Nasionalisme. 


\section{PENDAHULUAN}

Ilmu Pengetahuan Sosial (IPS) di Sekolah Dasar (SD) adalah mata pelajaran yang mempelajari manusia dalam semua aspek kehidupan dan interaksinya yang ada masyarakat. Kemudian tujuan pembelajaran IPS sendiri untuk memperkenalkan siswa kepada pengetahuan tentang kehidupan masyarakat secara sitematis (Suhanadji, 2003:1)

Pada jenjang Sekolah Dasar (SD) penanaman nilainilai nasionalisme melalui Pendidikan IPS mulai ditanamkan pada siswa, dengan cara pengenalan simbolsimbol kenegaraan, seperti pengenalan bendera negara, simbol-simbol atribut negara, lagu kebangsaan negara, dan pengenalan pada sejarah berdirinya negara, serta pengenalan pada pahlawan-pahlawan nasional bangsa (Sumaatmadja, 2007:4.22). Cerita sejarah lebih menekankan pada gambaran pribadi tokoh yang diceritakan, yaitu tentang sikap dan pribadinya. Misalnya cerita tentang Pangeran Dipenogoro, mengenai detail-detail ceritanya kurang ditekankan tetapi disesuaikan dengan tingkat perkembangan cara berpikir siswa SD. Cerita sejarah tentang Pangeran Dipenogoro yang ditonjolkan pada siswa SD adalah gambaran tentang perjuangan pangeran Dipenogoro sebagai orang yang relegius, taat pada ajaran agama, Pangeran Dipoegoro seorang pahlawan yang gagah berani dalam mengusir penjajah Belanda.

Nasionalisme merupakan bagian penting bagi berkehidupan bangsa dan negara. Nasionalisme saat ini dirasakan mulai terkikis di kalangan anak didik di sekolah dasar antara lain prilaku anak-anak usia dasar karena berbagai faktor, antara lain kurang tercermin dari figur tokoh pahlawan bahkan seorang pejuangan, apabila dibiarkan begitu saja maka keadaan ini akan berbahaya, sebab siswa SD merupakan generasi penerus bangsa yang akan melanjutkan perjuangan dan pembangunan bangsa menuju arah yang lebih baik. Sebagai contoh jika kita memperhatikan banyak anak-anak yang suka meniru gaya artis-artis dari luar negeri, misalnya Beyonce, Leady Gaga dari pada meneladani Tjoet Nja' Dhien (Cut Nyak Dien), Tjoet Nja' Meutia (Cut Nyak Meutia), Raden Ajeng Kartini, Raden Dewi Sartika, dan lebih hafal lagu Umberella dari pada lagu Indonesia Raya atau lagu daerah serta lagu-lagu nasional, lebih memilih tawuran ketimbang memikirkan pelajaran inilah ironis persoalan generasi bangsa, oleh karena itu perlu adanya nasionalisasi terhadap jati diri dan kepemilikian kearifan budaya lokal bangsa.

Banyak generasi penerus bangsa seperti anak-anak sekolah dasar yang memahami rasa nasionalisme hanya sebatas simbolisasi saja tidak sampai menerapkannya ke dalam aktivitas kehidupan sehari-hari (hanya ikut memperingati HUT RI, peringatan hari kesaktian
Pancasila, akan tetapi nilai-nilai implementasinya miskin sekali dari apa yang diharapkan terhadap pengamalannya selama dipelajari dan dipahami di sekolah). Hal ini dapat dibutikan bahwa anak-anak sekolah dasar selalu menganggap produk luar negeri lebih baik dari pada produk nasional, sehingga karakter serta nilai-nilai nasionalisme perlu ditanamkan sejak dini dalam diri anak agar dapat menjadi manusia yang dapat mencintai bangsa dan negara sendiri.

Pengenalan dan penanaman sikap nasionalisme salah satunya melalui pembelajaran IPS, dan salah satu media pengkomunikasian nasionalisme adalah buku teks. Buku teks merupakan salah satu sarana atau media penting dalam proses pembelajaran yang digunakan untuk membantu siswa dalam memahami materi pelajaran, meningkatkan pengetahuan dan kemampuan siswa.

Buku teks merupakan salah satu sarana pendidikan yang sangat penting dan strategis untuk menentukan keberhasilan dalam proses belajar mengajar siswa disekolah dan dirumah. Dari buku teks siswa dapat memperoleh berbagai informasi dan pengetahuan. Buku sekolah khususnya buku teks merupakan media intruksional yang dominan perannya dikelas atau dalam sebuah proses pembelajaran. Salah satu indikator bangsa yang maju adalah bangsa yang mempunyai tingkat kegemaran membaca berbagai masalah dan tantangan pada zamannya. Oleh karena itu, buku teks yang bermutu merupakan kebutuhan mutlak.

Buku yang berkualitas disesuaikan dengan standar kurikulum yang berlaku, terutama untuk meningkatkan kualitas pendidikan di Indonesia (Mursel, 1999:8). Namun isi/materi buku teks harus relevan dengan tuntutan isi kurikulum yang ada, dan harus relevan dengan standar kompetensi dan kompetensi dasar / inti yang harus dimiliki oleh lulusan tingkat SD/MI dalam usia perkembangan serta karakteristik siswa yang akan menggunakan buku teks tersebut. Sepertinya buku bahan ajar yang ada saat ini terdapat isi buku teks yang tidak sesuai dengan kurikulum yang berlaku yang terdapat dalam beberapa buku. Seperti kasus yang pernah terjadi pada tahun 2012 yang sempat menghebohkan dunia pendidikan yaitu kasus tentang adanya buku teks yang yang menyimpang materinya dan memuat bacaan tentang "istri simpanan" walaupun cerita itu tidak secara langsung tercantum istilah istri simpanan, tapi tutur katanya lebih halus, dimana hanya ditampilkan seseorang wanita disuruh mengganggu pernikahan suatu pasangan supaya bercerai (Yunni, 2012).

Dalam buku Ilmu Pengetahuan Sosial Terpadu yang disusun oleh Budi Hartawan untuk kelas 6 SD, pada halaman 30, di Bab 2 tentang Kenampakan Alam dan 
Keadaan Sosial dan Negara Tetangga, buku yang diterbitkan oleh penerbit Yudistira tahun 2010 tertulis bila kepala negara Thailand adalah Presiden. Padahal kepala negara dari sebuah sistem negara tersebut berbentuk kerajaan, tentu saja adalah raja. Mungkin yang dimaksud penulis adalah kepala pemerintahan. Tetapi itupun tidak tepat karena kepala pemerintahan negara Thailand adalah seorang Perdana Menteri (Setiawan, 2015).

Kesalahan fatal yang terjadi kekeliruan yang dituliskan pada halaman 129 buku Horizon Ilmu Pengetahuan Sosial kelas 4 SD. Di buku yang disusun oleh Drs Sudjatmoko Adisukarjo dan diterbitkan oleh penerbit Yudistira itu ditulis bila Dr Ir Soekarno wafat pada tanggal 21 Mei 1970. Sementara Bung Hatta dimakamkan di TMP Kalibata Jakarta Selatan. Padahal seharusnya Bung Karno wafat pada 21 Juni 1970. Sementara, Bung Hatta dimakamkan di Tanah Kusir Jakarta Selatan (Setiawan, 2015), melihat kenyataan data yang telah ditemukan menunjukan bahwa konten buku yang ada ditingkat sekolah perlu identifikasi dan kajian mendalam mengenai isi materi apakah sudah sesuai dengan maksud dan tujuan indikator SK dan KD / KI tingkat dan perkembangan anak SD serta sudah memenuhi standar isi buku yang layak untuk anak sekolah dasar.

Berangkat dari permasalahan di atas maka isi dari suatu buku teks harus relevan dengan kurikulum yang berlaku sehingga tidak terjadi permasalahan khususnya mengenai materi nasionalisme. Pelajaran di SD saat ini tidak bisa dipisahkan dari buku teks seperti halnya pelajaran Ilmu Pengetahuan Sosial (IPS) yang harus sesuai dengan kurikulum yang telah berlaku saat ini.

Sampai saat ini buku teks memegang peranan penting sebagai proses pembelajaran di sekolah maupun di rumah. Buku teks merupakan media yang sangat penting dan strategis dalam pendidikan. Buku teks berfungsi sebagai penarik minat belajar siswa. Sehingga dengan memiliki buku teks siswa lebih paham dengan pelajaran yang diberikan oleh guru dan sebagai pedoman belajar pada saat di rumah. Buku teks mempermudah siswa dalam dalam mengetahui dan memahami ilmu pengetahuan yang mereka ingin pelajari.

Berkaitan dengan pendidikan tidak lepas dari adanya kegiatan pembelajaran, yang merupakan suatu kegiatan melaksanakan isi kurikulum suatu lembaga pendidikan, agar dapat mempengaruhi para siswa mencapai tujuan pendidikan yang telah ditetapkan (Sudjana. 2007:1). Sehingga proses interaksi siswa dengan guru dan sumber belajar terjadi pada suatu lingkungan belajar. Selama proses pembelajaran ada kegiatan belajar yang dilakukan siswa dan ada kegiatatan mengajar yang dilakukan oleh guru dan ada materi pelajaran yang disampaikan oleh guru, di mana kegiatan ini tidak berlangsung sendiri-sendiri melainkan berlangsung secara bersama-sama pada waktu yang sama sehingga terjadi interaksi komunikasi aktif antara guru, siswa, dan materi pelajaran (Arifin. 2005:2).

Untuk mencapai tujuan pembelajaran dalam menyampaikan materi pelajaran, seorang guru biasanya menggunakan metode dan strategi yang sesuai dengan kemampuan guru. Media pengajaran dapat mendukung tercapainya kegiatan pembelajaran mengajar yang diharapakan dapat mencapai standar ketuntasan belajar. Buku teks merupakan salah satu media yang mendukung dalam suatu proses pembelajaran dan sebagai sarana pokok untuk belajar yang disusun oleh pakar dalam bidangnya. Digunakan pada jenjang tertentu dan dilengkapi dengan sarana pelajaran. Buku mempunyai banyak kelebihan dibandingkan dengan media belajar lainnya. Buku lebih mudah digunakan, mudah didapat, relatif murah harganya, tahan lama atau tidak mudah rusak, bisa dibaca dan mudah dibawa kemana-mana, menyajikan bermacam-macam informasi yang menambah daya kepintaran, dan menambah ilmu pengetahuan.

\section{METODE}

Penelitian ini merupakan jenis penelitian deskriptif kualitatif dengan metode analisis isi (content analysis). Analisis isi adalah teknik penelitian untuk membuat inferensi-inferensi yang dapat ditiru (replicable) dan sahih data dengan memperhatikan konteksnya. (Bungin, 2007:155).

Teknik analisis data yang digunakan untuk mengetahui ketersebaran dan keluasan narasi atau uraian yang mendeskripsikan tentang materi nasionalisme pada buku teks IPS adalah dengan cara conten analiysis.

Secara teknik Content analysis mencangkup upayaupaya klasifikasi lambang-lambang yang dipakai dalam komunikasi, menggunakan kriteria dalam klasifikasi, dan menggunakan prediksi dan menggunakan teknik tertentu dalam membuat prediksi (Muhadjir, 2000:68).

Berdasarkan teknik content analysis Bungin peneliti mengembangkan bahwa hal pertama yang dilakukan dalam penelitian ini adalah menentukan lambang atau simbol, dalam penelian ini berarti peneliti harus menentukan tematema utama nasionalisme yang kemudian dikembangkan menjadi indikator-indikator untuk masing-masing tema pada buku teks IPS SD berdasarkan kurikulum tingkat satuan pendidikan. Yang kedua mengkasifikasi data berdasarkan simbol/labang yang berarti peneliti mencocokkan variabel indikator nasionalisme dengan buku teks IPS SD berdasarkan kurikulum tingkat satuan 
pendidikan. Ketiga prediksi/analisis data disini peneliti mencocokkan materi apa saja yang sesuai dengan variabel indikator nasionalisme, kemudian hasil yang diperoleh diklasifikasi sesuai dengan tema nasionalisme.

\section{Sumber Data}

Data adalah unit informasi yang direkam dalam suatu media yang dapat dibedakan dengan data lain, dapat dianalisis dengan teknik-teknik yang ada, dan relevan dengan masalah yang diteliti (Zuchdi, 1993: 29). Data yang dikumpulkan dan dikaji dalam penelitian ini adalah data kualitatif. Sumber data dalam penelitian ini adalah Buku Sekolah Elektronik (BSE) IPS Kelas IV SD yang diterbitkan oleh Pusat Pembukuan Departemen Pendidikan yang dapat dilihat pada tabel berikut :

Tabel 1 Buku Sekolah Elektronik (BSE) kelas IV

\begin{tabular}{lll}
\hline No & \multicolumn{1}{c}{ Pengarang } & \multicolumn{1}{c}{ Judul Buku } \\
\hline 1 & & Ilmu \\
& & Pengetahuan \\
& Tantya Hisnu dan P. Winardi & Sosial Untuk \\
& & SD/MI \\
\hline 2 & & Cerdas \\
& Retno Heny Pujiati dan Umi & Pengetahuan \\
& Yuliati & Sosial Untuk \\
& & Kelas 4 SD/MI \\
\hline
\end{tabular}

Kedua buku tersebut akan yang diterbitkan oleh Pusat Pembukuan Departemen Pendidikan digunakan sebagai sumber data penelitian. Kemudian untuk memudahkankan penelitian dilakukan pengkodean sumber data penelitian yang dapat dilihat pada tabel berikut :

Tabel 2 Kode Buku Sekolah Elektronik (BSE) kelas IV

\begin{tabular}{|c|c|c|c|}
\hline No & Pengarang & Judul Buku & $\begin{array}{l}\text { Kode } \\
\text { Buku }\end{array}$ \\
\hline 1 & Tantya Hisnu dan & Ilmu Pengetahuan & Buku \\
\hline 1 & P. Winardi & Sosial Untuk SD/MI & I \\
\hline 2 & $\begin{array}{l}\text { Retno Heny } \\
\text { Pujiati dan Umi } \\
\text { Yuliati }\end{array}$ & $\begin{array}{l}\text { Cerdas Pengetahuan } \\
\text { Sosial Untuk Kelas } 4 \\
\text { SD/MI }\end{array}$ & $\begin{array}{c}\text { Buku } \\
\text { II }\end{array}$ \\
\hline
\end{tabular}

\section{HASIL DAN PEMBAHASAN}

\section{Sebaran Nasionalisme dalam Buku teks}

Berdasarkan pembahasan dalam bab IV, maka diperoleh data nasionalisme dengan indikator-indikator pencapaiannya telah di narasikan dalam bentuk yang berbeda-beda baik pada buku teks I maupun buku teks II. Hanya saja narasi yang ada diantara kedua buku teks tersebut berbeda-beda (lihat tabel).
Tabel 3 Sebaran Nasionalisme dalam Buku teks I \& II

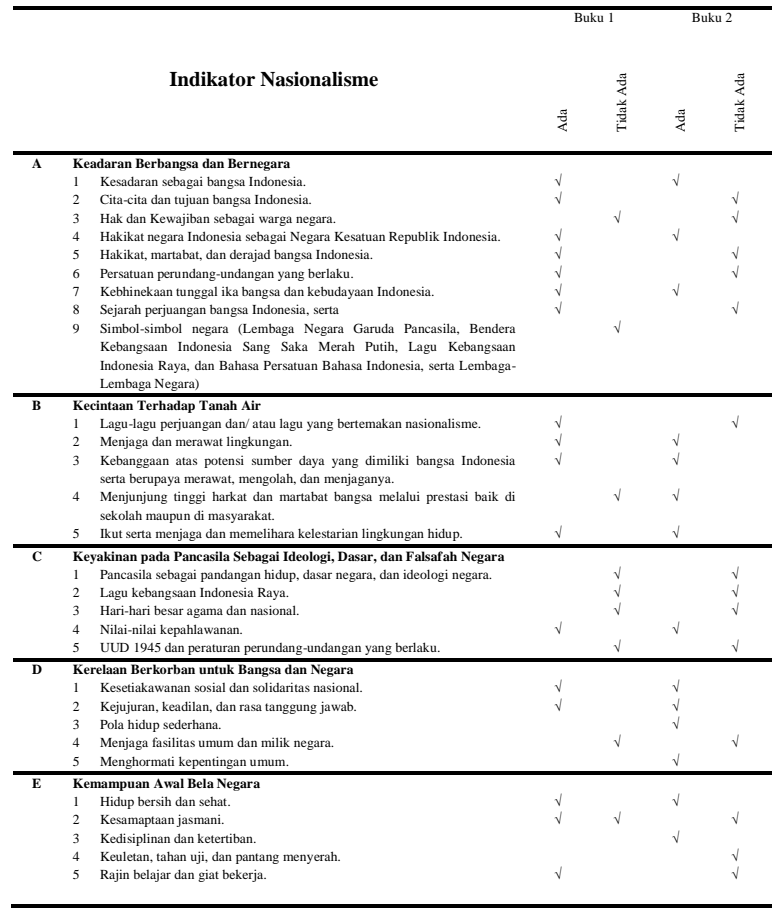

Pada buku teks I, berdasarkan tabel di atas, menunjukkan hampir seluruh indikator dalam setiap tema nasionalisme di narasikan atau diuraikan hal ini bisa dilihat pada bab IV. Tema kesadaran berbangsa dan bernegara, misalnya, hanya dua indikator yaitu: hak dan kewajiban sebagai warga Negara; dan simbol-simbol Negara (Lambang Negara Garuda Pancasila, Bendera Kebangsaan Indonesia) yang tidak dinarasikan. Sedangkan 8 (delapan) indikator lainnya dideskripsikan kedalam bentuk narasi.

Hal ini berbeda dengan buku teks II yang hanya 3 (tiga) dari delapan indikator yang dinarasikan lebih lanjut kedalam materi. Sedangkan lima indikator lainnya, diantaranya: cita-cita dan tujuan hidup bangsa Indonesia; hak dan kewajiban sebagai warga Negara; harkat, martabat, dan derajat bangsa Indonesia; peraturan perundangundangan yang berlaku; sejarah perjuangan bangsa Indonesia; dan simbol-simbol Negara (Lambang Negara Garuda Pancasila, Bendera Kebangsaan Indonesia) yang tidak dinarasikan tidak diuraikan sama sekali.

Demikian pula pada tema kecintaan terhadap tanah air yang menjadi bagian dari nasionalisme yang harus dicapai oleh peserta didik. Sebaran tema ini dalam buku teks I memiliki sebaran yang sama dengan buku teks II. Dari 5 (lima) indikator yang ada, hanya satu indikator yang tidak diuraikan kedalam bentuk narasi, yaitu indikator menjunjung tinggi harkat dan martabat bangsa melalui prestasi baik di sekolah maupun di masyarakat. 
Sebaliknya, buku teks II juga memuat 4 (empat) narasi sebagai pengembangan dari indikator. Indikator yang dinarasikan meliputi: menjaga dan merawat lingkungan; kebanggaan atas potensi sumber daya yang dimiliki oleh bangsa Indonesia serta berupaya merawat, mengolah, dan menjaganya; Sedangkan indikator lagu-lagu perjuangan dan atau yang bertemakan nasionalisme tidak dinarasikan.

Untuk tema keyakinan pada Pancasila sebagai ideologi, Dasar, dan Falsafah Negara, kedua buku teks belum memberikan penjelasan kedalam narasi secara merata. Hal ini dapat dilihat dari terpenuhinya narasi sebagai pengembangan dari masing-masing indikator yang ada. Dalam tema ini, baik buku teks I dan II hanya mengembangkan 1 (satu) narasi untuk indikator nilai-nilai kepahlawanan. Sedangkan 4 (empat) indikator lainnya, diantaranya: 1) Pancasila sebagai pandangan hidup, dasar negara, dan ideologi Negara; 2) lagu kebangsaan Indonesia Raya; 3) Hari-hari besar agama dan nasional; dan 4) UUD 1945 dan peraturan perundang-undangan yang berlaku.

Tema Kerelaan berkorban untuk Bangsa dan Negara juga dinarasikan berbeda sebarannya oleh kedua buku teks. Buku teks I hanya menarasikan dua indikator dari 5 (lima) yang ada, yakni: kesetiakawanan sosial dan solidaritas nasional; dan kejujuran, keadilan, dan rasa tanggung jawab. Sedangkan 3 (tiga) indikator lainnya tidak dinarasikan sama sekali.

Sedangkan buku teks II memberikan narasi lebih luas sebarannya dibanding dengan buku teks I. Sebanyak 4 indikator dinarasikan yang meliputi: 1) kesetiakawanan sosial dan solidaritas nasional; 2) kejujuran, keadilan, dan rasa tanggung jawab; 3) pola hidup sederhana; 4) menghormati kepentingan umum. Sedangkan hanya 1 (satu) indikator yakni menjaga fasilitas umum dan milik Negara tidak dinarasikan.

Untuk tema Kemampuan Awal Bela Negara, kedua buku teks memberikan narasi yang juga dengan sebaran berbeda. Buku teks I menarasikan 3 (tiga) indikator, dan 2 (dua) lainnya tidak dinarasikan. Sedangkan buku teks II hanya menarasikan 2 (dua) indikator yang dikembangkan kedalam bentuk narasi, yaitu: hidup bersih dan sehat; dan kedisiplinan dan ketertiban. Sedangkan 3 (tiga) indikator lainnya tidak dinarasikan, yakni: 1) kesehatan jasmani; 2) keuletan, tahan uji, dan pantang menyerah; dan 3) rajib belajar dan giat bekerja tidak dinarasikan.

Berdasarkan paparan di atas dapat diambil kesimpulan bahwa, secara umum sebaran narasi nasionalisme antara buku teks I dan II hampir merata. Hal ini ditandai oleh adanya narasi atau uraian materi untuk masing-masing tema nasionalisme. Hanya saja di level indikator yang berbeda antara kedua buku teks tersebut. Hampir semua indikator dalam tema-tema nasionalisme dikembangkan oleh buku teks I kedalam bentuk uraian materi. Sedangkan buku teks II hanya sebagian indikator yang dikembangkan.

\section{Keluasan Nasionalisme Buku teks}

Secara keseluruhan, tingkat keluasan narasi antara buku I dan II hampir sama. Hanya saja, buku teks I lebih luas dibanding dengan buku teks II dengan selisih 6 (enam) narasi. Buku teks I mendeskripsikan keseluruhan indikator untuk keseluruhan tema sebanyak 46 narasi atau uraian materi, sedangkan buku teks II sejumlah 40 narasi. Seperti yang dijelaskan pada tabel berikut.

Tabel 4 Keluasan Nasionalisme dalam Buku teks I \& II

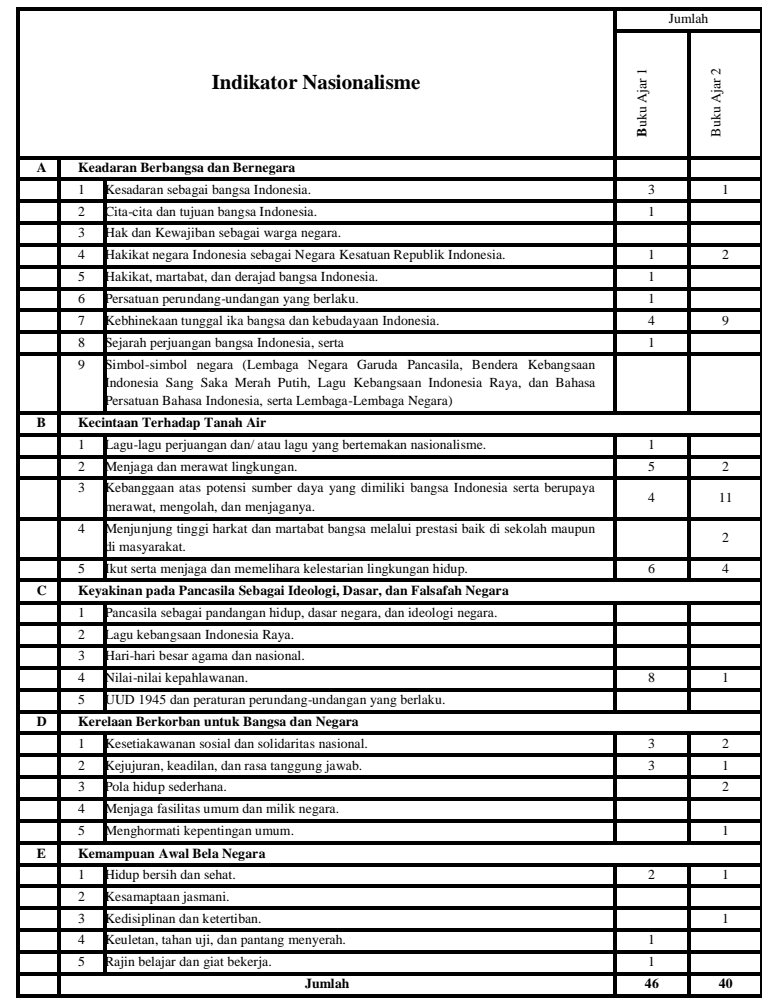

Materi nasionalisme yang di narasikan pada buku teks I maupun buku teks II sudah sesuai dengan standar kompetensi dan kompetensi dasar dalam kurikulum KTSP, materi yang disampaikan juga sudah merupakan penjabaran dari kompetensi dasar. Dari isi materi yang dijelaskan juga dapat dikatakan mutakhir, karena apa saja yang disampaikan dapat dipercaya kebenarannya. Seperti: Pada buku teks I bab IV tentang semangat kepahlawanan dan cinta tanah air dijelaskan bahwa salah satu cara kita untuk menghargai jasa para pahlawan yang telah gugur yakni dengan mengikuti upacara bendera setiap hari senin dan pada saat upacara juga menyanyikan lagu 
Mengheningkan Cipta untuk mendoakan para Pahlawan. Kegiatan-kegiatan tersebut sangat penting dilaksanakan untuk dapat mengingat betapa pentingnya cinta terhadap tanah air.

Sebagai contoh pada buku teks I halaman 108 tersebut dijelaskan bahwa salah satu cara kita menghargai jasa para Pahlawan adalah dengan mengikuti Upacara Bendera dengan hikmat dan untuk mendoakan para pahlawan yang telah gugur mendahului kita, saat upacara kita mengheningkan cipta. Dengan kegiatan tersebut tentu memiliki substansi keilmuan dan life skill dimana anak dilatih untuk membiasakan diri menghargai jasa para Pahlawan melalui kegiatan Upacara Bendera, kemudian mengheningkan cipta untuk mendoakan jasa para Pahlawan. Selain itu, life skill dari pembelajaran siswa dapat belajar bernyanyi, memiliki kemampuan bernyanyi yang baik terutama menyanyikan lagu Nasional atau kebangsaan. Tentunya menyanyikan Lagu Nasional dengan lagu pop biasa memiliki cara yang berbeda.

Secara keseluruhan materi nasionalisme yang dinarasikan dalam buku teks I dan buku teks II juga sudah menarasikan keberagaman Sumber Daya Alam (SDA) yang di miliki oleh bangsa Indonesia. Pengenalan SDA yang dimiliki oleh indonesia wajib dikenalkan sejak dini kepada peserta didik, supaya dapat digunakan secara bijak. Seperti halnya dijelaskan pada buku teks II pada bab tiga tenang sumber daya alam dan kegiatan ekonomi setempat halaman 61. Pada uraian materi tersebut peserta didik bukan hanya dikenalkan pada kekayaan SDA yang dimiliki oleh bangsa indonesia tetapi dituntuk untuk serta menjaga serta merawat kelestariannya, karena jika tidak dirawat akan punah.

Tema kesadaran berbangsa dan bernegara secara umum tema ini menyajikan materi yang terkandung dalam buku teks I dan II membawa peserta didik pada satu pemahaman tentang kondisi sosial masyarakat Indonesia yang beragam dari agama, suku, ras dan etnik. Meskipun demikian, keberagaman tersebut dianggap sebagai berkah tidak sebagai sebuah ancaman. Perspektif ini memunculkan usaha untuk membiasakan peserta didik hidup rukun dalam kemajemukan mulai dari tingkatan keluarga, sekolah dan masyarakat.

Pada buku teks II bab 4 tentang keanekaragaman suku dan budaya setempat halaman 71 dijelaskan bahwa negara Indonesia merupakan negara kepulauan. Pulaupulau di Indonesia berjumlah 13.777 pulau besar dan kecil. Dengan banyaknya jumlah pulau yang ada di indonesia memungkinkan muncul dan berkembangnya keragaman suku dan budaya bangsa. Seperti yang dijelaskan pada buku teks II halaman 73.
Keragaman suku ini memunculkan berbagai macam budaya yang menunjukkan ciri dari suku tersebut. Budaya ini bisa berbentuk tari daerah, bahasa daerah, dan cara berpakaian. Misalnya, di Jawa Barat ada Suku Sunda, di Papua ada Suku Asmat. Bahasa daerah Jawa Barat disebut Bahasa Sunda sangat berbeda dengan Bahasa Papua. Tarian daerah pun berbeda, Jawa Barat terkenal dengan Tari Jaipong dan Papua terkenal dengan Tari Musyo. Ternyata penduduk Indonesia sangat beragam. Karena itulah, negara kita Indonesia memiliki semboyan Bhinneka Tunggal Ika.

Istilah Bhinneka Tunggal Ika diambil dari Kitab Sutasoma karangan Mpu Tantular yang ditulis pada masa Kerajaan Majapahit. Bhinneka Tunggal Ika berarti walaupun berbeda-beda tetapi tetap satu jua. Saat itu, di Kerajaan Majapahit sedang berkembang agama Hindu dan Buddha. Walaupun memiliki keyakinan agama yang berbeda, tetapi penganut dua agama ini dapat hidup berdampingan dengan tenteram. Selanjutnya, istilah Bhinneka Tunggal Ika digunakan menjadi semboyan Indonesia. Semboyan ini menggugah kesadaran untuk tetap bersatu dalam Negara Kesatuan Republik Indonesia (NKRI).

Pada buku teks I dan buku teks II telah Mengidentifikasi keragaman budaya yang terdapat di Indonesia, menjelaskan keragaman bangsa Indonesia, menjelaskan bentuk-bentuk keragaman suku bangsa dan budaya, menjelaskan adat dan kebiasaan setempat, menghargai keragaman suku bangsa dan budaya, mengidentifikasi kenampakan alam, sosial, dan budaya setempat, menjelaskan hubungan kenampakan alam, sosial, dan budaya dengan gejalanya, dan mengembangkan sikap menghormati budaya di Indonesia merupakan beberapa Kompetensi Dasar yang harus dimiliki oleh peserta didik dalam mata pelajaran IPS.

Rumah adat, pakaian, alat musik, tari-tarian, dan bentuk rumah menjadi pintu masuk peserta didik untuk mengenal komunitas lain di luar asalnya. Pengenalan ini menjadi penting karena dengan pemahaman atas yang lain, peserta didik memhami entitas lain yang juga hidup di bumi Indonesia.

Keragaman lain dapat dilihat pada alat musik khas daerah-daerah yang ada di Indonesia, yaitu angklung (Jawa Barat), kecapi, gerdek (alat musik tiup yang berasal dari Kalimantan Barat, Kalimantan Tengah, dan Kalimantan Timur), saluang dan Telempong Pacik (Sumatra Barat), sasando (Nusa Tenggara Timur), serunai (alat musik tiup yang berasal dari Sumatra Utara), rebab (alat musik gesek dari Jawa Barat dan Jawa Tengah), gamelan (Bali dan Jawa), alosu dan Anak Becing (Sulawesi Selatan), dan 
aramba (alat musik berbentuk seperti gong kecil, berasal dari Nias).

Keragaman senjata tradisional. Senjata tradisional yang terdapat di Indonesia, antara lain rencong (Aceh), keris (Jawa, Bali, dan Gorontalo). Mandau (Kalimantan Timur), terapang (Lampung), piso surit (Sumatra Utara), kujang (Jawa Timur)

Kehadiran sebuah bangsa yang memahami bahwa dirinya memiliki kesamaan asal dan sejarah yang sama tidaklah mudah. Jika dahulu pada awal kemerdekaan, para pendiri bangsa dengan mudahnya disatukan oleh perasaaan bahwa mereka memiliki nasib yang sama yaitu penderitaan karena dijajah dan dengan itu mereka melakukan sebuah perlawawanan atas nama satu bangsa, maka zaman sekarang tidak mudah untuk menyamakan platform kebangsaan tersebut.

IPS sebagai mata pelajaran mengemban misi penyamaan platform kebangsaan berusaha menumbuhkan rasa tersebut dengan menyajikan materi yang mendorong masyarakat untuk melakukan transfer nilai sosial kepada peserta didik. Tugas ini menjadi mungkin dilakukan karena negara memiliki kemampuan itu dengan memasukkannya dalam standar kompetensi dan kompetensi dasar yang terdapat dalam buku teks.

Secara umum materi dalam buku teks membawa peserta didik pada satu pemahaman tentang kondisi sosial masyarakat Indonesia yang beragam dari agama, suku, ras dan etnik. Meskipun demikian, keberagaman tersebut dianggap sebagai berkah tidak sebagai sebuah ancaman. Perspektif ini memunculkan usaha untuk membiasakan peserta didik hidup rukun dalam kemajemukan mulai dari tingkatan keluarga, sekolah dan masyarakat.

Ruang-ruang yang memungkinkan peserta didik untuk berinteraksi menjadi lokus pemahaman tentang keberagaman. Mereka harus memiliki perspektif plurasime dalam berinteraksi. Kerjasama menjadi jembatan dalam membiasakan hidup rukun. Tidak saja dianggap sebagai aktivitas yang bermanfaat secara individu dan sosial. Mengetahui bentuk bentuk kerja sama di lingkungan tetangga serta menyebutkan kegunaannya merupakan indikator yang digunakan untuk membiasakan pola hidup ini.

Agar tidak menjadi pengetahuan yang abstrak dan hanya menjadi ingatan, peserta didik diberi tugas untuk memberikan contoh bentuk-bentuk kerjasama tersebut. Mereka bisa mengidentifikasi dengan contoh-contoh di lingkungna mereka. Pemahaman ini akan mendorong pada konklusi tentang manfaat yang bisa dipetik dari kerjasama.

Pada satu titik ketika mereka sudah memahami kemajemukan dan penemuan kerjasama ditengah kemajemukan itu, diharapkan peserta didik memiliki kepekaan terhadap persoalan sosial dan mampu untuk mengatasinya. Dengan demikian, persoalan sosial yang dipahami dan dipecahkan secara bersama-sama merupakan bentuk negara dalam menyemai benih bahwa sesama masyarakat merupakan bagian yang tak terpisahkan. Apabila ada satu yang sakit, maka kewajiban yang lain untuk menyembuhkannya.

Secara keseluruhan materi nasionalisme yang disajikan telah kontekstual, apa yang di uraikan oleh buku teks I maupun buku teks II adalah persoaalan nyata yang sesuai dengan kehidupan sehari-hari. Uraian materi yang disajikan juga sudah memuat kecakapan akademik, mengajak siswa berpikir, praktek, kerja langsung, serta kecakapan sosial, materi yang disajikan juga telah melibatkan kegiatan sehari-hari, kehidupan sehari-hari, melibatkan masalah-masalah sosial sehari-hari yang ada dilingkungan peserta didik.

Uraian materi nasionalisme yang terdapat pada buku teks I maupun buku teks II sebagaian besar pembahasannya telah sesuai dan proporsional tanpa mengabaikan standar kompetensi dan kompetensi dasar kurikulum KTSP. Materi naionalime yang di uraikan pada buku teks I maupun buku teks II juga melatih peserta didik untuk membuat hubungan sebab-akibat, yang sesuai dengan tujuan pembelajaran.

\section{PENUTUP}

\section{Simpulan}

Dari hasil temuan-temuan peneliti dalam menjawab rumusan masalah, dapat disimpulkan bahwa isi materi tema nasionalime yang dinarasikan dalam buku bahan ajar berbentuk yang berbeda-beda baik dalam isi buku teks I maupun isi buku teks II. Dari keluasan materipun juga berbeda dimana buku teks I lebih luas dari pada buku teks II dalam menguraikan indikator-indikator nasionalisme, karena hampir semua indikator nasionalisme telah di uraikan pada buku teks.

Seperti pada buku teks I tema kesadaran berbangsa dan bernegara pada indikator harkat, martabat, dan derajat bangsa Indonesia. Indikator materi tersebut di uraian dalam narasi, sedangkan pada buku teks II indikator materi tersebut tidak di uraikan dalam narasi. Pada tema kecintaan terhadap tanah air indikator tentang menjunjung tinggi harkat dan martabat bangsa melalui prestasi baik di sekolah maupun di masyarakat. Pada buku teks I indikator tersebut tidak di uraiakan dalam narasi, tapi pada buku teks II di indikator materi tersebut di uraikan dalam narasi.

Uraian materi nasionalisme yang terdapat pada buku teks I maupun buku teks II sebagaian besar pembahasannya 
telah sesuai dan proporsional tanpa mengabaikan standar kompetensi dan kompetensi dasar kurikulum KTSP. Materi naionalime yang di uraikan pada buku teks I maupun buku teks II juga melatih peserta didik untuk membuat hubungan sebab-akibat, yang sesuai dengan tujuan pembelajaran.

Secara keseluruhan materi nasionalisme yang disajikan telah kontekstual, apa yang di uraikan oleh buku teks I dan buku teks II adalah persoalan nyata yang sesuai dengan kehidupan sehari-hari. Uraian materi yang disajikan juga sudah memuat kecakapan akademik, mengajak siswa berpikir, praktek, kerja langsung, serta kecakapan sosial, materi yang disajikan juga telah melibatkan kegiatan sehari-hari, kehidupan sehari-hari, melibatkan masalahmasalah sosial sehari-hari yang ada dilingkungan peserta didik.

\section{Saran}

Ada beberapa hal yang disarankan untuk penulis buku teks IPS sebagai pihak yang berperan dalam implementasi kurikulum, seyogyanya mengetahui dan memahami visi dan misi bidang studi IPS khususnya dalam nasionalisme. Agar siswa berminat untuk mempelajari buku pelajaran, penulis seyogyanya menyajikan hal-hal yang tidak asig bagi siswa. Untuk itu dapat digunakan contoh yang akrab dengan kehidupan siswa. Dengan kata lain penulis seyogyanya banyak masuk dalam lingkungan yang ada yang ada disekitar siswa.

\section{DAFTAR PUSTAKA}

Aman. (2014). Aktualisasi Nilai-Nilai Kesadaran Sejarah dan Nasionalisme Dalam Pembelajaran Sejarah di SMA. Jurnal Pendidikan Karakter. Ed. Februari No.1. pp. 23-34.

Amri, Sofan. Jauhari, Ahmad. Elisah, Tatik. (2011). Implementasi Pendidikan Karakter Dalam Pembelajaran (Stategi analisis dan pengembangan karakter siswa dalam proses pembelajaran). Jakarta: Prestasi Pustakaraya.

Anderson Benedict. (2008). Imagined Communities (Komunitas - komunitas Terbayang. Yogyakarta: INSIST dan Pustaka Pelajar,

Anthony D. Smith. (2004). History and National Destiny: Responses and Clarifications, Nations and Nationalism 10 (1/2, 195-209, 198.

Bungin, Burhan. (2007) Penelitian Kualitatif (komunikasi, ekonomi, kenijakan publik, dan ilmu sosial lainnya), Jakarta: Kencana Prenada Media Group,
Bungin, Burhan. (2012) Analisis Data Penelitian Kualitatif (Pemahaman filosofis dan metodologis ke arah penguasaan model aplikasi). Jakarta: Grafindo Persada.

Connelly F. Michael dan Clandinin, D. Jean. (1988). Teacher as Curriculum Planners. Amsterdam Vanue: Teacher College Press.

David Brown. (1999). Are there Good and Bad Nationalism. Nations and Nationalism, 5 (2), 282.

Detiknews, duh! Istri Simpanan, Perebutan Wanita \& Sadis di Buku Anak SD/MI. 2012 (http://news.detik.com/berita/1892038/duh-istrisimpanan-perebutan-wanita-sadisme-di-bukuanak-sd diakses 13 Desember 2015).

Dinas Pendidikan. (2010). Pedoman Teknis Pengintegrasian Materi Nasionalisme melalui Jalur Pendidikan Bagi SD/MI. Dinas Pendidikan Provinsi Jawa Tengah.

Dokumen Peraturan Menteri Pendiidkan Nasional Republik Indonesia No 11 Tahun Tahun 2005, Tentang Buku Teks Pelajaran.

Haryati, Mimin. (2008). Model dan Teknik Penilaian pada Tingkat Satuan Pendidikan. Jakarta: Gaung Persada Press.

Henry Guntur Tarigan, dkk. (1993). Telaah Buku Teks Bahasa Indonesia. Bandung: Angkasa.

Hidayati. (2002) Pendidikan Ilmu Pengetahuan Sosial di Sekolah Dasar. Yogyakarta: Program D-II PGSD FIP UNY.

Khaeruddin. Junaedi, Mahfud. (2007) Kurikulum Tingkat Satuan Pendidikan (Konsep dan Implementasinya di Madrasah). Jogyakarta: Nuansa Aksara.

KPAI. Setiawan Davit. (2015). Pola Kosumsi Miras Dikalangan Remaja Meningkat, (http://www.kpai.go.id/berita/kpai-polakonsumsi-miras-dikalangan-remaja-meningkat/ dikases 20 Nopember 2015).

KPAI. Setiawan Davit. (2015). Pelaku Kekarasan Terhadap Anak Tiap Tahun Meningkat. (http://www.kpai.go.id/berita/kpai-pelakukekerasan-terhadap-anak-tiap-tahun-meningkat/ dikases 21 Nopember 2015).

Mary Kaldor. (2004). Nationalism and Globalization. Nations and Nationalism 10 (1/2). Pp. 103-128.

Muhadjir, Noeng. (2000). Metodologi Penelitian Kualitatif. Yogyakarta: Rake Sarasin. 
Mulyanti Arifin. (2005). Strategi Belajar Mengajar. Malang: UIN Press.

Mulyasa. (2007). Kurikulum Tingkat Satuan Pendidikan (Suatu panduan praktis). Bandung: Remaja Rosydakarya.

Mursel, J. dan Nasution, S. (1999). Mengajar dengan Sukses, Jakarta: Bumi Aksara.

Muslich, Mansur. (2012). KTSP Dasar Pemahaman dan Pengembangan (Pedoman bagi pengelola lembaga pendidikan, pengawas sekolah, kepala sekolah, komite sekolah, dewan sekolah, dam guru). Jakarta: Bumi Aksara.

Nana, Sudjana. (2007). Media Pengajaran. Bandung: Sinar Baru Algensindo.

Pratt, David. (1980). Curriculum Design and Development, New York: Harcourt Brace Javanovich Publishers.

Rohman Arif. (2009). Politik Idiologi Pendidikan. Yogyakarta: Laksbang Mediatama.

Rukiyati, dkk. (2008). Pendidikan Pancasila. Yogyakarta: UNY Press.

Rosana, Dadan. (2014). Penguatan Kurikulum dengan Pendidikan Kewirausahaan dan Pembelajaran Aktif untuk Pengembangan Karakter Bangsa. Jurnal Pendidikan Karakter. Ed. Juni No.2. pp. 160-174.

Sapriya. (2012). Pendidikan IPS (Konsep dan Pembelajaran). Bandung: Remaja Rosydakarya.

Sitepu. (2012). Penulisan Buku Teks Pelajaran. Bandung: Remaja Rosydakarya.

Skripsi jurusan kependidikan sekolah dasar, fakultas ilmu pendiidkan UM. (2012). Website: repository um.ac.id, universitas malang. (http://karyailmiah.um.ac.id/index.php/KSDP/article/view/19 042 dikases 22 September 2015).

Smith, D Anthony. (2012) Nasionalisme Teori Ideologi Sejarah. Jakarta: Erlangga.

Suara Merdeka, Mungin Edi Wibowo. (2005). Hati-hati Menggunakan Buku Pelajaran. (http://www.suaramerdeka.com/harian/0508/09/ opi04.htm diakses 12 Desembe 2015).

Sudrajat, Ajat. (2011). Mengapa Pendidikan Karakter. Jurnal Pendidikan Karakter. Ed. Juni No.2, pp.47-58.

Suhanadji. \& Waspodo Tjipto Subroto. (2003). Pendidikan IPS. Surabaya: Insan Cendikia.
Sumaatmadja Nursid. (1997). Materi Pokok Konsep Dasar IPS. Jakarta: Universitas Terbuka.

Sumaatmadja, Nursid. (1980). Metodologi Pengajaran Ilmu Pengetahuan Sosial. Bandung: Alumni.

Sumaatmadja, Nursid. (2007). Konsep Dasar IPS. Jakarta: Universitas Terbuka.

Sunarso, dkk. (2008). Pendidikan Kewarganegaraan PKN Untuk Perguruan Tinggi. Yogyakarta: UNY Press.

Sutiyono. (2013). Penerapan Pendidikan Budi Pekerti Sebagai Pembentukan Karakter Siswa di Sekolah: Sebuah Fenomena dan Realitas. Jurnal Pendidikan Karakter. Ed.Oktober No.3, pp. 309-320.

Suyitno, Imam. (2012). Pengembangan Pendidikan Karakter dan Budaya Bangsa Berawawasan Kearifan Lokal. Jurnal Pendidikan Karakter. Ed. Februari No.1, pp. 1-13

Tempo.Co Nasonal. Yuni, Imam. (2012). Kontroversi Istri Simpanan di buku kelas 2 SD (http://nasional.tempo.co/read/news/2012/04/13/ 079396764/kontroversi-istri-simpanan-di-bukukelas-2-sd dikases 21 September 2015).

Tilaar, H.A.R. (2006). Standarisasi Pendidikan Nasional (Suatu Tinjauan Kritis). Jakarta: Rineka cipta.

Trianto. (2010). Model Pembelajaran Terpadu. Jakarta: Bumi Aksara 